\title{
Effects of Covid-19 on Crude Oil Price and Future Forecast Using a Model Application and Machine Learning
}

\author{
Azubuike H. Amadi, Orisa F. Ebube, Silas I. Aire and Chigoziri B. Marcus
}

\begin{abstract}
Oil Price has been a benchmark governing the trade of oil and gas globally. It is fixed by producing countries or countries in a consortium through organizations such as Organization of the Petroleum Exporting Countries (OPEC) or a particular mix of crude oil such as the West Texas Intermediate (WTI) or Brent. The spot price and future prices of crude oil is basically determined by demand and supply, however, some external factors can have great influence on oil price. This research work will be emphasizing on the direct and indirect effects of the COVID-19 pandemic as an external factor other than demand and supply on the benchmarks of oil pricing between 2000 and 2020 . Having analyzed the various oil price fluctuation which have been caused by several factors over the years, this research went further to identify those significant factors, weigh them and input them into a model that will generate simulated oil prices of past, present and future benchmarks with relation to demand, supply, production cost and other external factors. This model was also validated using machine learning algorithms and real data of previous yearly average oil price noting the reasons for each spot price. Significant recommendations were made on the use of this model for fixing oil price benchmarks as variables to each benchmark are numerous.
\end{abstract}

Index Terms - B-PEST analysis, Oil price, Benchmark, Crude oil, COVID-19, Pandemic, Matlab, Machine learning, Supply and Demand, WTI, Brent, OPEC, Spot price, Future Price.

\section{INTRODUCTION}

Oil pricing has dated back to the commercial oil drills in Pennsylvania, USA in 1959 and a spike owning to about half of the world's oil [4]. Crude oil price was within $\$ 0.49$ to $\$ 6.59$ from 1861 to 1865 [4]. Gradually, the worth and necessity of crude oil was increasing geometrically and significant events happening around the world started having huge influence on the price of crude oil. Basically, the price of crude oil as a marketer should be based on the production cost (which is critically calculated from the exploration stage to first oil and consequently maintenance) and a reasonable profit margin added depending on the

Published on December 4, 2020.

A. H. Amadi, World Bank Africa Center of Excellence in Oilfield Chemical Research, University of Portharcourt, Nigeria.

(e-mail: azubuikehopeamadi@gmail.com).

E. F. Orisa, Emerald Energy Institute, University of Portharcourt, Nigeria. (e-mail: ebubeorisa@ ${ }^{@}$ ahoo.com).

S. I. Aire, Institute of Petroleum Studies, University of Portharcourt, Nigeria.

(e-mail: aire.silas@yahoo.com).

C. B. Marcus, Ignatius Ajuru University of Education, Nigeria.

(e-mail: chigozirimarcus@yahoo.com). competitiveness of the market. However, the case is slightly different because of the importance attached to the black gold (crude oil). A bulk of events ranging from political to technological to biological to geographical, etc. tends to heavily impact on the pricing of the crude oil. Some significant events over the years that led to fluctuations of oil price have been spotted, such as; the US Civil War and Oil boom within 1862 to 1865 , the Spindletop oil discovery in 1901, World War I that spanned from 1914 to 1918 , the 1920 Gas Famine in the West Coast, the Great Economic Depression of 1929, the 1939 to 1945 World War II, the Suez Crisis or 2nd Arab-Israeli War of 1956, the Yom Kippur War in 1973, Iranian Revolution or Islamic Revolution from 1970 to 1980 , The Oil Glut's in the 1980s, the War between Iraq and Iran from 1980 to 1988, the Gulf War from 1990 to 1991, the 1997 Financial Crisis in Asia, the Iraq War from 2003 to 2011, the Arab Spring which started with protest in Tunisia from 2010 to 2012 [15], US Shale Oil production innovation from 2014 to 2016, OPEC production cuts from 2016 to 2018, COVID-19 Pandemic from 2019 till date [14]. All these events are either affecting the major buyer of Crude Oil or major sellers or both.



Fig. 1. Plots of Oil Price trends [6].

Each incident above has affected the oil price in one way or the other as shown in the fluctuation of oil price in Fig. 1, but for the purpose of this work, we will be analyzing the COVID-19 effect on the oil price.

The World Health Organization has described the COVID-19 as a new discovery of Corona virus which is infectious and easily transmitted from person to person. The disease outbreak which has gotten its name COVID-19 from the year of discovery was said to be first documented in Wuhan, Hubei Province, China in December 2019. Since December 2019 till date the corona virus has spread 
gradually across the world resulting to a Pandemic of great concern.

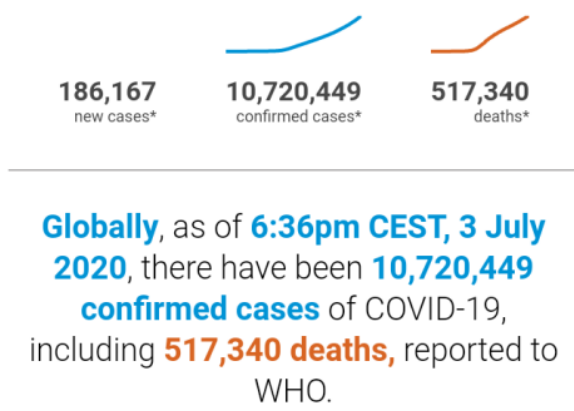

Fig. 2. WHO report on COVID-19 [14]

The Pandemic has resulted in the shutdown of several economic activities across the world in a bid to curb the fatality inflicted by the spread. This turnaround of events has had an indirect effect on the Crude Oil price benchmark of the OPEC Basket, WTI and Brent leading to a steep drop in the oil price. However, efforts are being made to improve the price of crude for the purpose of profit and sustainability as a handful of countries depends on revenue from crude oil.

\section{ANALYSIS OF COVID-19 AgAINST CRUDE OIL}

The effect of COVID-19 on crude oil prices cannot be over emphasis. On 20th April 2020, for the first time in history, the price of WTI, the benchmark for United States oil fell to negative 37.63USD per barrel meaning producers pay buyers to take crude from them due to fear that storage capacity could run out [1]. Fig. 3 shows the all of WTI during the COVID-19 pandemic. As the global lockdown restricted movements, the demand for crude oil fell, and producers resorted to renting tankers to store the excess oil and it caused the prices to negative. Although, the US as at 30th March, 2020 has the highest record of COVID-19 cases, the impact of the virus to the rest of the world cannot go under the curtains especially to mono-economic countries whose economy sole depend on the performance of the oil industry.

After the discovery of oil in Nigeria in the late 1950's, crude oil has been the backbone of the country's economy, contributing about $80 \%$ of the government revenue and is a major source of foreign exchange earnings and Foreign Direct Investments (FDIs) [2]. On the 11th of June 2020, the Nigerian National Assembly passed a revised budget of 10.8 trillion Naira from 10.5 trillion Naira reason for the difference being to respond to the effect of COVID-19 [8], [9]. The oil benchmark was also reduced from $\$ 57$ to $\$ 28$ and GDP projection reduced from $2.93 \%$ to $-4.41 \%$ in 2020 . The Nigerian Finance Minister, Zainab Ahmed tied the reason for these developments to a $65 \%$ decline in projected government revenues from the oil and gas sector [8], [9].

Nigeria's production cost for Crude Oil is estimated to be about $\$ 30$ per barrel, which posed a huge problem for the country when the oil price reduced drastically during the early periods Covid-19 pandemic impact [3]. The further drop of price got the OPEC Basket to sell at a negative price, meaning that the cost of production is now higher than the selling price. This dilemma can be well understood from the aspect that, there is crude oil but no one to sell to, so the producers are now underpriced to be able to unload tankers while production is going on or we could also say that the price of the Crude oil future contract falls below zero (this is because, the spot price is supposed to be lower than future). Asides the direct impact on oil prices, oil production is also threatened as many onshore and especially offshore oilfields have resulted to reducing work capacity or at worse shutting the field for fear of rising COVID-19 cases.

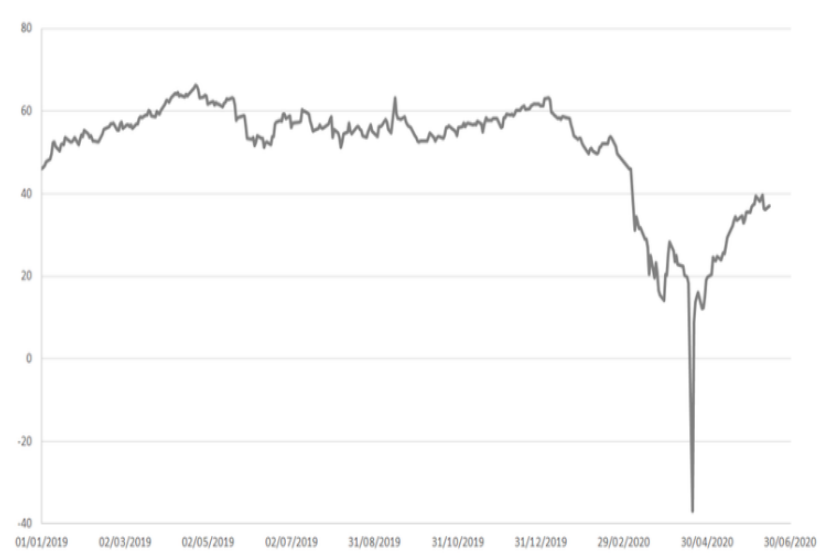

Fig. 3. A monthly trend of WTI Oil Price during the COVID-19 period [13]

\section{ANALYSIS OF CRUDE OIL BENCHMARK}

In the early 1960s the Government Take per Barrel (T) was calculated using the formula:

$$
T=(P-C) s
$$

where:

$\mathrm{P}=$ Oil Price or Posted Price.

$\mathrm{C}=$ Estimated Cost of Production

$\mathrm{s}=$ tax rate on Notional Profit $(0<\mathrm{s}<1)$.

In 1964, following the inclusion of Royalty in OPEC bargain, Government Take per Barrel (T) was now:

$$
\begin{aligned}
& T=(P-C) s+\operatorname{Pr}(1-s) \\
& \text { at } \\
& s=0.5 \\
& \text { or } \\
& T=a P-b \\
& \text { where: } \\
& \begin{array}{l}
a=s+r-r s \\
(a>0) \\
b=C s \\
(b>0) \\
(0<r<1)
\end{array}
\end{aligned}
$$

where $r=$ royalty rate.

The Government Selling Price (GSP) or Original Selling Price (OSP) took a front stage in 1975 and GSP was equivalent to $0.93 \mathrm{P}$, around the 1980 s OPEC prices skewed to the GSP's of Member Countries.

Crude oil pricing is affected by Crude oil quality (such as 
Gravity, Sulfur content, etc.) and distance between exporting points and main market among other factors.

In 1977 there was a dual system of oil pricing recommended by OPEC which favored the Arabian Light and affected other member countries; however, there was a reuniting of the pricing system at the later part of 1977. In 1981 the Arabian Marker price was raised by $\$ 2$ and the deemer marker was reduced by $\$ 2$. The $50 / 50$ criterion has always been used to balance such challenges.

\section{A. Model Application}

We can make the Oil price the subject of the formula from equation 2 and input the various factors that can affect it.

$$
P=\frac{T+b}{a}
$$

\section{B. Factors Affecting Pricing of Oil}

We will be discussing the PEST Analysis and how it contributes to the crude oil pricing.

PEST stands for:

$\mathrm{P}$ - Political

E - Economical

$\mathrm{S}-$ Social

\section{T - Technological}

For the purpose of this research work we will be adding a new factor while analyzing the Crude Oil pricing factors, which is Biological. This is because of the tremendous effect the COVID-19 pandemic has had on the crude oil pricing. Therefore, the method of analysis will now be BPEST Analysis, with B standing for Biological.

Significant Factors affecting Oil Price:

\section{1) Biological}

We can classify its severity on a scale of -0.3 to 0 , of which 0 was regarded as NO Effect, -0.3 will serve as High severity such as the COVID-19 Pandemic.

\section{2) Political}

Policies and government leadership patterns can affect the pricing of oil. An example is the Arabian Spring in the early 2010 who's causes where traced to Political Corruption, human right violation, Authoritarianism, etc. leading to deaths of about 100,000 [15]. Political factors were weighed on a scale of -0.5 to 1 . When the effect is affecting oil price negatively it tends to -0.5 , while positive effects tends to 1 .

\section{3) Economical}

A typical example of an economic factor was the great economic recession of 1929, where the rate of unemployment across countries was high, records of high falls in stock prices, low personal income, tax reduction, profits decline, etc. this affects both poor and rich countries. It affects oil price because both the buyers and sellers are caught up in this crisis simultaneously. So, for the purpose of this research work, we will be weighing the impact on a scale of -0.5 to 0.7 . 0 was regarded as NO Effect, -0.5 will serve as High severity, while 0.7 signifies a good economic balance

\section{4) Social}

This will be seen as crisis such as War, affecting major producing or buying countries. It was weighed on a scale of
-0.5 to 0 , with -0.5 signifying severe war affecting producing and buying countries and 0 for no war.

\section{5) Technology}

Technology can affect the price of oil in different positively and negatively. The tech for improving the oil recovery can lead to high oil production, tech could also cut down the production cost, tech could also bring up unconventional ways of recovering oil, making countries with less expectation of oil to swing to high reserves. Therefore, the technological impact will be weighed on a scale of -0.5 to 1 . When a country or an organization is using their technology to affect the crude business negatively it will be tending to -0.5 on the scale, while a positive effect will tend to 1 .

$$
\begin{aligned}
& \text { C. Summary of Weighing Factor } \\
& \text { Biological factors, } b_{f}=-0.3 \text { to } 0 \\
& \text { Political factors, } p_{f}=-0.5 \text { to } 1 \\
& \text { Economic factors, } e_{f}=-0.5 \text { to } 0.7 \\
& \text { Social factors, } s_{f}=-0.5 \text { to } 0 \\
& \text { Technological factors, } t_{f}=-0.5 \text { to } 1 \\
& P=\frac{T+b}{a} \times \exp \left(b_{f}+p_{f}+e_{f}+s_{f}+t_{f}\right)
\end{aligned}
$$

The Exponential function in Equation 4 was developed to cater for the external factors affecting oil pricing because exponents are best used in analyzing real world situations, while the factors can be manipulated within the given ranges to meet the present or future forecast.

Example:

Assuming the estimated cost of production is $\$ 30$, a tax rate on notional profit of 0.5 , a royalty rate of 0.05 and the government has estimated to have a Take of $\$ 50$ per barrel.

The estimated oil price will be:

$$
\begin{aligned}
P & =\frac{50+30 \times 0.5}{0.5+0.05-0.05 \times 0.5} \times \exp \left(b_{f}+p_{f}+e_{f}+s_{f}+t_{f}\right) \\
P & =\$ 123.81 \times \exp \left(b_{f}+p_{f}+e_{f}+s_{f}+t_{f}\right)
\end{aligned}
$$

The cost of crude oil is $\$ 123.81$ without considering the impact of the external factors.

However, if there is a war at the major oil producing Arab nations weighed at about -0.2 and the major buyer like China is undergoing an economic recession weighed at about -0.1 , the price of crude oil will be affected following the pricing model developed.

$$
\begin{aligned}
& P=\$ 123.81 \times \exp (0+0-0.1-0.2+0) \\
& P=\$ 91.72
\end{aligned}
$$

This external effect cost the price of crude oil to fall to $\$ 91.72$ which is a significant drop in price.

\section{Validation of Model}

Trying to validate the extent of consistency of this model to real life scenarios, lots of variables are to be considered.

For organized setups like OPEC, the cost of production varies, while the Government Take per barrel also varies across member countries. Therefore, it will be preferable to 
use a country that determines its own price.

Fig. 6 shows the cost of Crude oil production of different countries as at 2016. However, according the Patti and Tom (2016), the WTI crude oil price fell to \$26.19 while Brent fell to 27.10 which were its weakest since May, 2003 [8]. At 2015, US Energy Information Administration (EIA) predicted the crude oil price for 2016 to be around $\$ 54$ per barrel for WTI while Brent was to trade at \$5 ahead of WTI [12].

Using the oil price estimate, with the influence of external factors as shown below:

$$
P=\$ 54 \times \exp \left(b_{f}+p_{f}+e_{f}+s_{f}+t_{f}\right)
$$

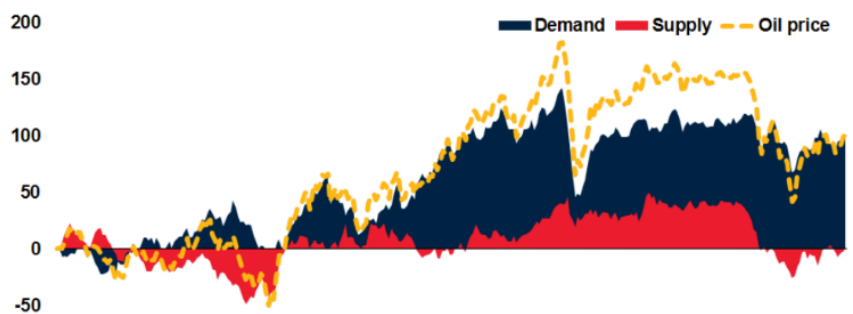

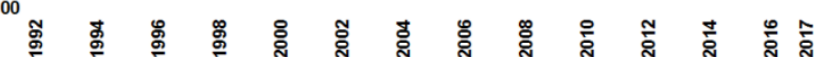

Fig. 4. Plot of Oil price variations showing the drop in 2016 [7].

Analyzing the cause of the drop to $\$ 26.19$ in February 2016 as shown in Fig. 4, we found that it was due to OPEC policies and oil cuts, increased shale oil production, tensions between Russia and Saudi Arabia on oil policies, etc. [7]. This can generally be seen as Political factors with little technological influence. However, we weighed this influence to be within the range of $-0.4 \mathrm{p}_{\mathrm{f}}$ and $-0.1 \mathrm{t}_{\mathrm{f}}$.

$$
\begin{aligned}
& P=\$ 54 \times \exp (0-0.4+0+0-0.18) \\
& P=\$ 30.23
\end{aligned}
$$

We are having an oil price drop to $\$ 30.23$ compared to $\$ 26.19$, showing that the model is sufficient enough to analyze crude oil price during variations of future price and spot price.

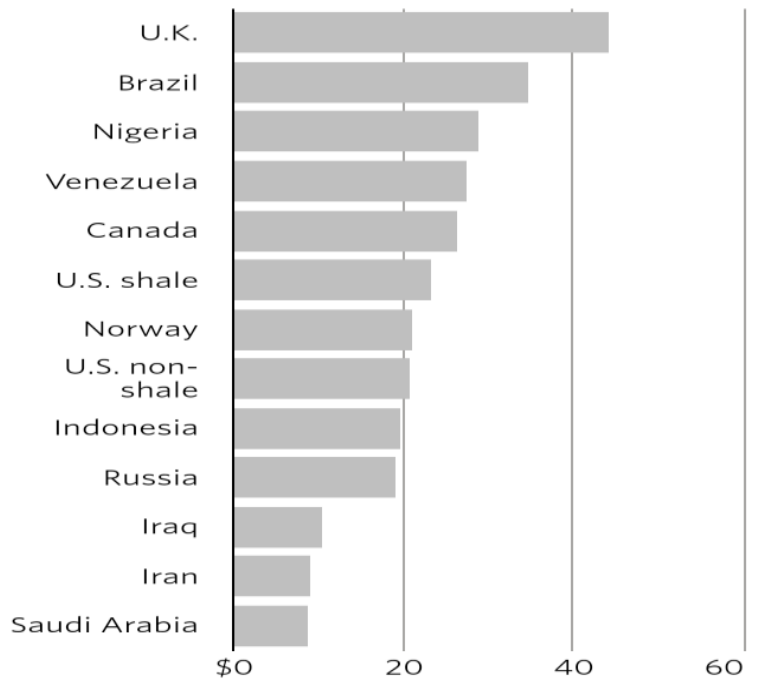

Fig. 5. Cost of oil production at 2016 [16].

\section{Simulation OF OIL PRICE USING Matlab} POLYNOMIAL REGRESSION (POLYVAL AND POLYFIT)

The use of machine learning and deep learning algorithms have shown to be of good use in the prediction of future values following trends just as used by Ledisi et. al. (2020) in the prediction of the Great British Pound (GBP) and Euros (EUR) annual average exchange rates for 2020 and 2022. Similar simulation was done with the use of MATLAB for future forecast for 2022, 2024 and 2026 Crude Oil average annual price.

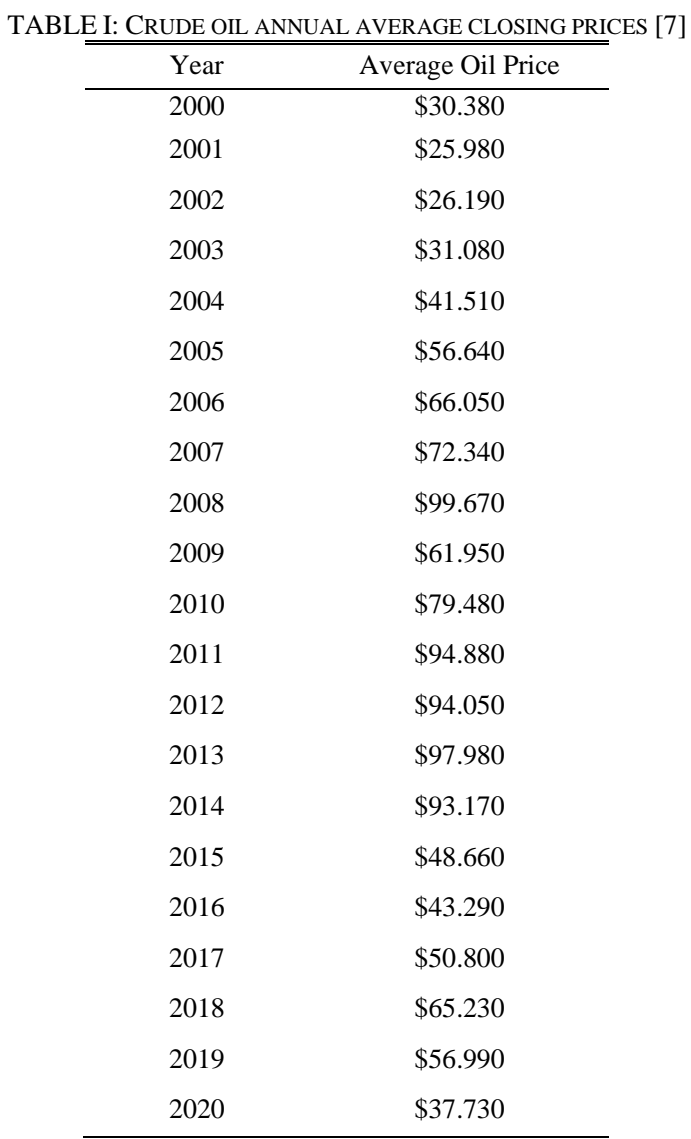

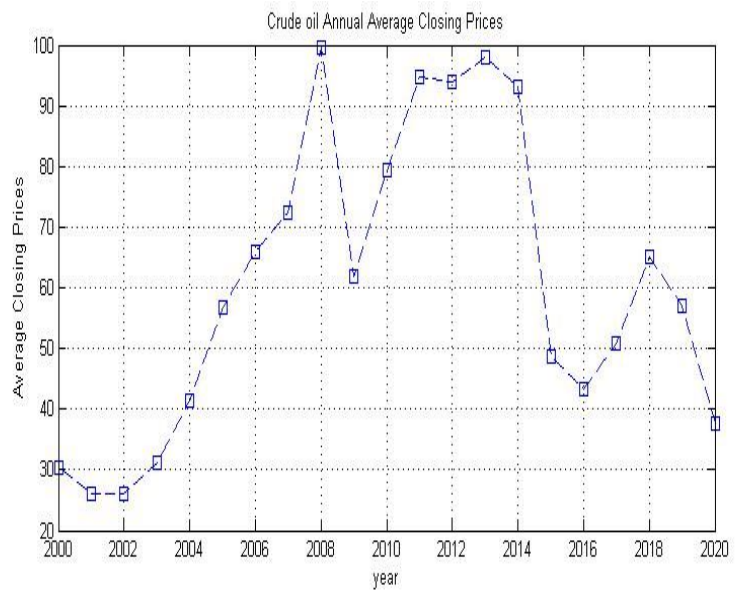

Fig.6. Crude Oil Average Oil Closing Price using MATLAB 2016a.

A plot of Table 1 (Average Crude oil price against Year) gave a trend as shown in Fig. 6 of which we used the Polynomial regression for polyfit and polyval during Matlab simulation as shown in Fig. 6 to make predictions for 2022, 2024 and 2026. 
Average_Oil_Price.m $\times$ Canada.m $\times+$

1 - year $=0$ il_Price $(:, 1)$;

2 - Price $=$ Oil_Price $(:, 2)$;

3 - plot (year, Price, '--bs')

4 - title('Crude oil Annual Average Closing Prices')

5 - xlabel ('year')

6 - ylabel ('Average Closing Prices')

7 - polyfit (year, Price, 1 )

$8-\quad p=$ polyfit (year, Price, 1);

$9-\mathrm{pp}=\operatorname{polyval}(\mathrm{p}, 2026)$;

10 - hold on

11 - plot (year, pp, '-r')

12 - grid on

Fig. 7. Matlab program of polynomial regression for Crude oil prediction.

The results show that the Average Crude Oil Annual Price will be at $\$ \mathbf{7 5 . 9 5}$ in $2022, \mathbf{\$ 7 8 . 5 0}$ in 2024 and $\mathbf{\$ 8 1 . 0 5}$ in 2026.

However, these results can't be relied on because, the impact of external factors is inevitable as long as there are trade of commodity and competitions among producing and receiving countries.

\section{CONCLUSION}

The COVID-19 pandemic brought about unprecedented disruptions in global supply chains, quick reduction in crude oil price, international travel restrictions and disrupt in the financial market.

The petroleum industry is dominant and oil prices can greatly affect the developmental rate in several nations. It is evident that several external factors as outlined can adversely affect crude oil prices. This work shows a simplistic approach to compute and predict crude oil prices by considering some inevitable external factors.

From the simulation, we have been able to predict the average annual prices for year 2022, 2024, and 2026. To achieve this, we evaluated the WTI crude oil price data from 2000 to 2020. However, these results can't be relied on because, the impact of external factors might not follow a regular trend as long as there are trade of commodity and competitions among producing and receiving countries. Regardless, the model generated could give an improved lead on fixing oil prices with respect to present conditions and long term estimates for contract purposes.

\section{RECOMMENDATION}

We observed that the model generated is sensitive to the varying parameters or scenarios. Therefore, this simulation can be improved on by:

- Integrating some deep learning-based model to predict crude oil prices.

- The model can be made more accurate by computing the monthly average of crude oil prices.

It merits further research in developing other models to predict future crude oil prices.

\section{ACKNOWLEDGMENT}

Our appreciation goes to all lecturers and Batch 16 postgraduate students at the Institute of Petroleum Studies, Port Harcourt.

\section{REFERENCES}

[1] BBC News, 2020. Business News. Retrieved from: https://www.dpr.gov.ng/dpr-rolls-out-measures-for-oil-industrysurvival/ 31 July, 2020.

[2] DPR. 2020. DPR Rolls Out Measures for Oil Industry Survival. Retrieved form: https://www.dpr.gov.ng/dpr-rolls-out-measures-foroil-industry-survival/. 31 July, 2020.

[3] Catherine H. C., Jeremy R. B. and Mark Acton (2003). Application of Exponential Functions, AlgebraLAB. Retrieved from: http://www.algebralab.org/lessons/lesson.aspx?file=Algebra_Exponen tsApps.xml.

[4] Emmanuel A. (2020, March 12). Nigeria plans to support oil price with lower production cost per barrel, Nairametrics: Business News Retrieved from: https://nairametrics.com/2020/03/12/Nigeria-plansto-support-oil-price-with-lower-production-cost-per-barrel/.

[5] IG (2019). History of Crude https://www.ig.com/uk/commodities/oil/history-of-crude-oil-price.

[6] Ledisi G., Marcus B. and Eneotu J. (2020). Machine Learning Algorithmic Study of the Naira Exchange Rate, European Journal of Engineering Research and Science 5(2): 183-186.

[7] Macrotrends (2020) Crude oil Prices - 70 Year Historical Chart Retrieved from: www.macrotrends.net/1369/crude-oil-price-historychart.

[8] Marc S., John B. and Dana V. (2018, January 18). What triggered the oil price plunge of 2014-2016 and why it failed to delivered an economic impetus in eight charts, World Bank Blogs. Retrieved 22 July, 2020.

[9] Nairametrics, 2020. BLURB. Retrieved from https://nairametrics.com/2020/07/15/2020-revised-budget-spendinginefficiencies-and-a-looming-debt-hole/, 31 July, 2020.

[10] Nairametrics, 2020. Economy and Policy. Retrieved from https://nairametrics.com/2020/07/10/buhari-signs-n10-8-trillionrevised-2020-budget/, 31 July, 2020.

[11] Patti D. and Tom D. (2016, January 20). US oil falls on unexpectedly large inventory build, CNBC News: Energy. Retrieved from: https://www.google.com/amp/s/www.cnbc.com/amp/2016/01/19/oilprices-fall-further-on-glut-worries-us-crude-slumps-below-28.html frf20 July, 2020

[12] Robert M. (1984). On Oil Price Concepts, Oxford Institute for Energy Studies, 57 Woodstock Road, Oxford OXZ 6FA England ISBN: 0948061022.

[13] Sean Hill (2015, August 19). EIA lowers crude oil price forecast through 2016, US Energy Information Administration. Retrieved on 21, July 2020.

[14] Sheppard D., McCormick M., Brower D. and Lockett H. (2020, April 20) US oil price below zero for first time in history, Financial Times. Retrieved 20 July, 2020.

[15] WHO (2020). Coronavirus Retrieved from: https://www.who.int/health-topics/coronavirus\#tab=tab_1.

[16] Wikipedia (2020). Arab Spring Retrieved from: https://en.m.wikipedia.org/wiki/Arab_Spring\#Summary_of_conflicts_ by_country

[17] WSJ News Graphics (2016, April 15) Cost of producing a barrel of oil and gas, The Wall Street Journal. Retrieved 20 July, 2020. 